\title{
The Role of Internal Control in Enhancing Corporate Governance: Evidence from Jordan
}

\author{
Inaam M. Al-Zwyalif ${ }^{1}$ \\ ${ }^{1}$ Department of Accounting, Faculty of Economics and Administrative Sciences, Al-Zaytoonah University of \\ Jordan, Jordan \\ Correspondence: Inaam M. Al-Zwyalif, Department of Accounting, Faculty of Economics and Administrative \\ Sciences, Al-Zaytoonah University of Jordan, P.O. Box 130 Amman 11733, Jordan. Tel: 962-6429-1511. E-mail: \\ inaamz2011@gmail.com
}

Received: January 29, 2015

Accepted: April 27, $2015 \quad$ Online Published: June 20, 2015

doi:10.5539/ijbm.v10n7p57

URL: http://dx.doi.org/10.5539/ijbm.v10n7p57

\begin{abstract}
This study aimed to examine the role of internal control elements: control environment, risk assessment, control activities, communication and information, and monitoring, in enhancing the corporate governance pillars, which are: accountability, fairness, responsibility, and transparency. The study also seeks to determine the extent to which this commitment contributes to strengthening these pillars in the context of Jordanian insurance companies.

In order to achieve the objectives of this study, a questionnaire was developed and distributed to a sample of non-executive members of the board of directors, financial managers, heads of accounting departments and internal auditors of 27 Jordanian insurance companies. The total number of questionnaires distributed was 162 questionnaires, of which 123 questionnaires were returned and were valid for data analysis, with a response rate of approximately $76 \%$.

Based on the results of the statistical analysis, the study indicated that the commitment to all elements of internal control contributes to strengthening the corporate governance pillars at a high degree. The study also revealed that the commitment to each element of internal control contribute to strengthening the pillars of corporate governance at a high degree. These results show that the internal control has a significant role in enhancing the corporate governance pillars in Jordanian insurance companies, and the successes of corporate governance requires compliance with all elements of internal control.
\end{abstract}

Keywords: role, corporate governance, internal control, Jordan

\section{Introduction}

Over the recent years, corporate governance has become a key focus in practice and academic literature as a direct result of highly publicized cases of corporate misconduct and business collapse. Furthermore, failures in corporate governance practices have been linked to the recent global financial crisis. There is also a growing realization that good corporate governance can help in avoiding problems and can provide many advantages. So, the corporate governance is still an exciting examination question, especially in emerging economies like Jordan. Corporate governance has been defined as a manner by which companies are directed and controlled. It is acknowledged that good corporate governance cannot exist without internal control. This leads to considering the role of internal control in corporate governance.

In view of that, the study seeks to answer the following main question: what role is played by the commitment to internal control elements for enhancing the pillars of corporate governance?

The sub questions that can be derived from the previous question are:

1). What role is played by the commitment to a control environment for enhancing the pillars of corporate governance?

2). What role is played by the commitment to risk assessment for enhancing the pillars of corporate governance?

3). What role is played by the commitment to control activities for enhancing the pillars of corporate governance? 
4). What role is played by the commitment to information and communication for enhancing the pillars of corporate governance?

5). What role is played by the commitment to monitoring for enhancing the pillars of corporate governance?

The primary aim of this study is to examine the role of commitment to the elements of internal control: control environment, risk assessment, control activities, communication and information, and monitoring, in enhancing the corporate governance pillars, which are: accountability, fairness, responsibility, and transparency. The paper also seeks to determine the extent to which this commitment contributes to strengthening these pillars in the context of Jordanian insurance companies.

The importance of the study springs from the role that internal control elements can play in the promotion of corporate governance. It attempts to contribute to the corporate governance literature, concerning the relationship between the internal control and corporate governance in Jordan as an example of a developing country, and helps to attract attention to the role of internal control in strengthening corporate governance systems. As for the practical aspect, this study will has implications for senior management and internal auditors in Jordanian insurance companies by providing insight into the relationship between corporate governance and internal control.

The paper proceeds as follows. The next section provides the theoretical background and the relevant literature. Section 3 briefly presents the corporate governance in Jordan. Section 4 presents the development of hypotheses. Section 5 describes the methodology. Section 6 introduces the results of the study and discussion. The final section concludes the paper.

\section{Theoretical Background and Literature Review}

The researchers define the concept of corporate governance in different ways depending on their perspective. According to The Organization for Economic Co-operation and Development (OECD) (2004), corporate governance is the rules and practices that govern the relationship between the managers and shareholders of corporations, as well as stakeholders like employees and creditors. It contributes to growth and financial stability by reinforcement of market confidence, financial market integrity and economic efficiency. Aguilera and Jackson (2003) defined corporate governance as the distribution of privileges and accountabilities amongst numerous performers who are involved in the corporate organization. The Cadbury Committee, in turn, stated that corporate governance refers to the system by which companies are directed and controlled (Dunne and Morris, 2008). In view of Lin and Liu (2009) corporate governance is a fanciful term for the way managers and auditors fulfill their responsibilities to shareholders. Also, Monks and Minow (2004) defined corporate governance as the relationship among various participants in determining the direction and performance of corporations.

In 1999, the OECD issued principles of corporate governance to support the development of legal and institutional frameworks. The OECD principles were adopted by the 30 member countries of the OECD. The principles were revised in 2004 to respond to corporate governance developments including corporate scandals that further focused the minds of governments on improving corporate governance practices (Jesover \& Kirkpatrick, 2005). These Principles cover six key areas: ensuring the basis for an effective corporate governance framework; the rights of shareholders; the equitable treatment of shareholders; the role of stakeholders in corporate governance; disclosure and transparency; and responsibilities of the board of directors (OECD, 2004).

Failures in corporate governance practices have been linked to the recent global financial crisis. So, there is a growing realization that good corporate governance can help in avoiding problems and can provide many advantages. A key reason for the interest in corporate governance and many of the current prescriptions for best practice is that they are needed for an efficient market and to facilitate economic growth (Rankin, Stanton, McGowan, Ferlauto, \& Tilling, 2012). Good corporate governance maximizes the profitability and long-term value of the firm for shareholders (Stone, Hurly, \& Khumani, 1998). Empirical studies indicate that international investors now better realize the significance of corporate governance practices on the financial performance of companies and while adopting investment decisions, international investors believe that this issue bears more importance for countries that are in need of reforms, and that they are more ready to pay higher premiums for companies having sound corporate governance practices (Yuksel, 2008).

One of the ways to develop good governance practices in an organization is to ensure that the pillars of corporate governance are in place in that organization.

There are four primary pillars of corporate governance that include (King Committee on Corporate Governance, 2002). 
Accountability: Directors who make decisions and take actions should be held accountable for their decisions and actions to stakeholders. Mechanisms must be in place to ensure accountability.

Fairness: All stakeholders should receive equal and unbiased consideration by the directors and management. The rights of various groups have to be recognized and valued.

Responsibility: Directors must carry out their duties with honesty and integrity. Responsible management would, when required, put in place what it would take to set the organization on the right path.

Transparency: This is a measure of how good management is at making necessary information available in an open, precise and timely manner.

Good corporate governance cannot exist without internal control. This leads to considering the role of internal control in corporate governance. Internal control is the process implemented by the board of directors and management to provide reasonable assurance that the following objectives are achieved: safeguarding assets, compliance with applicable laws and regulations, reliability and transparency of financial reporting, and efficiency and effectiveness of operations (Romney \& Steinbart, 2006). As described by Khan (1994), internal controls are designed to protect an institution from loss or misuse of its assets, as well as to ensure that all transactions are properly authorized and thus guarantee or foster good corporate governance.

Robbins (1992) indicated that the internal control system is the whole system of controls, financial and otherwise, established by management in order to carry out the business of the enterprise in an orderly and efficient manner, ensure adherence to management, safeguard the assets and secure as far as possible the completeness and accuracy of the records.

According to The Committee of Sponsoring Organizations of the Treadway Commission (COSO) in the year 1992, internal control systems have five primary elements (components) as listed below (Weygandt, Kimmel, \& Kieso, 2011).

A control environment: It is the responsibility of top management to make it clear that the organization values integrity and that unethical activity will not be tolerated. This component is often referred to as the "tone at the top".

Risk assessment: Companies must identify and analyze the various factors that create risk for the business and must determine how to manage these risks.

Control activities: To reduce the occurrence of fraud, management must design policies and procedures to address the specific risks faced by the company.

Information and communication: The internal control system must capture and communicate all pertinent information both down and up the organization, as well as communicate information to appropriate external parties.

Monitoring: internal control systems must be monitored periodically for their adequacy. Significant deficiencies need to be reported to top management and/ or the board of directors.

There are three main types of internal controls: preventative, detective and corrective. Preventive controls deter problems before they arise. Detective controls are needed to discover problems as soon as they arise. Corrective controls remedy control problems that have been discovered. Also, internal controls are often segregated into two categories: general controls and application controls. General controls are designed to make sure an organization's control environment is stable and well managed. Application controls prevent, detect, and correct transaction errors and fraud (Romney \& Steinbart, 2006).

Several studies stated that an effective internal control system is essential to achieve sound corporate governance practice. Mensah, Aboagye, Addo, and Buatsi (2003) found empirical evidence in Ghana that effective internal control improved good governance practices and decreased the corruptions. Steinthórsdóttir (2004) concluded that internal control is a very important element of corporate governance, and internal audit adds value to the organization by assessing the control systems and reporting that assessment to the board and management, which in turn use it as a measure of the "health" of the organizational system. Ping and Wen-hua (2007) studied the reciprocal relationship between corporate governance and internal control. The results showed that the strengthening of internal control promotes the realization of corporate governance. Viriyanti (2008) demonstrated that internal control had a positive link with good corporate governance at State Owned Enterprises in Indonesia. Bosetti (2008) argued that there is strong integration between corporate governance and management control; particularly, this latter helps reach the balance of effectiveness and efficiency in operational activities. Hoitash, Hoitash, and Bedard (2009) examined the association between corporate governance and 
disclosures of material weaknesses in internal control over financial reporting. The study concluded that board and audit committee characteristics are associated with internal control quality. Susanty (2009) investigated the relationship between internal functions of the organization and the successful implementation of good corporate governance principles (GCG). The study showed that internal function of the organization gives support to the successful implementation of GCG principles. Elbannan (2009) suggested that corporate governance strength is positively related to internal control quality in U.S. firms disclosing internal control weaknesses in their Securities and Exchange Commission filings.

Leng and Ding (2011) aimed to research the influence of corporate governance structure on internal control disclosure. They discovered that internal control disclosure is positively related to directors' remuneration, two part-time posts of chairman and general manager, directors' education level and supervisors' education level, and it negatively related to the proportion of state ownership. Adeyemi and Adenugba (2011) study examined the efficacy of internal controls and external audit in corporate governance and observed the extent to which both of them have had an impact on corporate governance practices. The study revealed that both internal controls and external audit are to a large extent accountable for bad corporate governance. Njanike, Mutengezanwa, and Gombarume (2011) discovered that failure to effectively implement internal controls contributed significantly to poor corporate governance. Lepadatu (2011) argued that better corporate governance requires the adoption of a methodical approach to risk management to protect the interests of stakeholders and shareholders, as well as ensure the existence of operational controls. Johnstone, $\mathrm{Li}$, and Rupley (2011) provided evidence that changes in corporate governance characteristics occur concurrently with the remediation of internal control material weaknesses. Dănescu, Prozan, and Dănescu (2011) emphasized that the elaboration and the implementation of adequate internal control activities will lead to good corporate governance. Mihaela and Iulian (2012) asserted that corporate governance and internal control should not be considered and sustained independence. An organization without an efficient long-term view of leadership and effective internal control mechanisms cannot be sustainable. So, corporate governance is not entirely effective without a good internal control. Suyono and Hariyanto (2012) showed that internal control, internal audit, and organization commitment have a positive significant relationship with the good governance in Indonesia. Vlad (2012) argued that the key elements of solid corporative governance include adequate internal control systems and transparency. Fadilah (2013) indicated that the implementation of internal controls provides a greater contribution to the implementation of good governance.

\section{Corporate Governance in Jordan}

Corporate governance in Jordan covers six areas: a legislative framework and government oversight, a capital market, disclosure and accounting standards, transparency in privatization, effective supervision of the board of directors, preservation of property rights and protection of minority rights (Khoury, 2003). These areas are addressed in the Company Law of 1997 and its mandates of 2002, and some in the Securities Law of 2002. The controller of a company exerts a crucial role in enforcing the corporate-governance provisions of the Company Law (Shanikat \& Abbadi, 2011). Also, Jordan has recently introduced Code of Corporate Governance, which adopts the OECD Principles, through the Companies Control Department (CCD). This Code will be specifically applicable to the following organizations: private shareholding companies, limited liability companies, and non-listed public shareholding companies. The Code is divided into 5 sections: the Board of directors/management committee-roles and responsibilities, control environment, transparency and disclosure, rights of shareholders/partners, and stakeholders (CCD, 2012).

\section{Study Hypotheses}

Based on the previous literature review, the researcher developed the main hypothesis and the sub-hypotheses as clarified below.

H1: The commitment to internal control elements (control environment, risk assessment, control activities, information and communication, and monitoring) enhances the pillars of corporate governance (accountability, fairness, responsibility, and transparency).

From this main hypothesis the following five sub- hypotheses can be derived:

H1/1: The commitment to control environment enhances the pillars of corporate governance.

H1/2: The commitment to risk assessment enhances the pillars of corporate governance.

H1/3: The commitment to control activities enhances the pillars of corporate governance.

H1/4: The commitment to information and communication enhances the pillars of corporate governance. 
H1/5: The commitment to monitoring enhances the pillars of corporate governance.

\section{Research Methodology}

\subsection{Research Population and Sample}

The Jordanian insurance sector was chosen for the application of this study because it has a growing need for good corporate governance systems in order to create an insurance sector capable of satisfying the economy's needs, as well as preserving its ability to face increasing demands and enhance trust in insurance companies. The number of insurance companies existing in the Jordanian market as in 2013 has reached (27) companies (Jordan Insurance Federation, 2013). The study included a sample of non-executive members of the board of directors, financial managers, heads of accounting departments and internal auditors of 27 Jordanian insurance companies. 162 questionnaires have been distributed to these companies, of which 123 questionnaires were returned and were valid for data analysis, with a response rate of approximately $76 \%$.

\subsection{Data Collection Instrument}

Data were collected using a questionnaire consisting of two parts: The first part aimed to identify the position of the respondent, while the second focused on the role of internal control elements (control environment, risk assessment, control activities, information and communication, and monitoring) in strengthening the pillars of corporate governance.

To investigate the validity of the questionnaire, some academics in Jordanian universities were consulted to examine the relevancy of the questionnaire to the study objectives. In addition, a pilot test was done on a sample of 20 participants who were not included in the sample frame for the subsequent data collection. The reliability test was applied to examine the internal consistency of the research instrument. The Cronbach's alpha coefficient was 0.93 which confirms the reliability of the questionnaire.

A Likert five-point scale was used to examine participants' responses to questionnaire statements, where the weight (5) was given to the situation of "strongly agree", (4) to the situation of "agree", (3) to the neutral case, (2) to "disagree", and (1) to "strongly disagree". Based on this scale, the arithmetic means are explained as follows:

1- 2.49 =Low, 2.5-3.49= Medium and 3.5 $-5=$ High .

\subsection{Data Analysis Method}

Statistical techniques were applied in the analysis by using the mean, standard deviation, percentage and frequency. Also one sample t-test was applied to test the study hypotheses.

\section{Results and Discussion}

\subsection{Distribution of the Sample}

Table 1 shows the distribution of respondents according to the position.

The table illustrates that $27.6 \%$ of the sample in the position of a member of the Board of Directors. As well $20.3 \%$ of the respondents were in financial manager position, $21.1 \%$ in head of accounting department position and $31 \%$ in internal auditor position.

Table 1. Distribution of the sample according to the position

\begin{tabular}{lll}
\hline Positions & Frequency & Percent \\
\hline Member of the board of directors & 34 & $27.6 \%$ \\
Financial manager & 25 & $20.3 \%$ \\
Head of accounting department & 26 & $21.1 \%$ \\
Internal auditor & 38 & $31 \%$ \\
Total & 123 & $100 \%$ \\
\hline
\end{tabular}

\subsection{Contribution of Commitment to Internal Control Elements to Strengthening the Pillars of Corporate Governance}

Table 2 shows the means and standard deviations of the paragraphs relating to the contribution of commitment to the control environment to strengthen the pillars of corporate governance. It points out that the means of the respondents' answers on all paragraphs separately were more than 3.5, also the overall mean of these answers on all paragraphs as a whole was 4.56 and the standard deviation was 0.61 . Clearly, respondents believe that the 
commitment to control environment contribute to a high degree in strengthening those pillars.

Also Table 2 demonstrates mean and standard deviation of the contribution of commitment to the risk assessment to strengthen the pillars of corporate governance. The mean for all answers about this area and the standard deviation were 4.75 and 0.58 , respectively. The mean was greater than 3.5 , this means that the participants believe that the commitment to risk assessment contribute to a high degree in strengthening those pillars.

The table also shows the mean and standard deviation of the contribution of commitment to the control activities to strengthen the pillars of corporate governance.

The mean for all answers here was 4.79 , which is greater than 3.5 , and the standard deviation was 0.61 . This result indicates that the respondents believe that the commitment to control activities contribute to a high degree in strengthening those pillars.

This table also shows the means and standard deviations of the paragraphs relating to the contribution of the information and communication to strengthen the pillars of corporate governance. It indicates that the means of the respondents' answers on these paragraphs were more than 3.5, also the overall mean of these answers on all paragraphs was 4.61 and the standard deviation was 0.67. Obviously, the respondents believe that the commitment to information and communication contribute to a high degree in strengthening those pillars.

Table 2 also illustrates the mean and standard deviation of the contribution of commitment to the monitoring to strengthen the pillars of corporate governance. The mean for all answers about this area and the standard deviation were 4.84 and 0.53 , respectively. The mean was greater than 3.5 , which indicate that the participants believe that the commitment to monitoring contribute to a high degree in strengthening those pillars.

Furthermore, table 2 shows the overall mean and standard deviation of the respondents' answers on all the paragraphs pertaining to the contribution of commitment to the elements of internal control. It illustrates that the overall mean of respondents' answers was more than 3.5, also the overall mean and the standard deviation of these answers were 4.71 and 0.65 , respectively, which mean that the commitment to all elements of internal control contribute to a high degree in strengthening the pillars of corporate governance.

Table 2. Descriptive statistics related to the contribution of commitment to internal control elements to strengthening the pillars of corporate governance

\begin{tabular}{|c|c|c|c|}
\hline Items & Mean & $\begin{array}{l}\text { Standard } \\
\text { Deviation }\end{array}$ & $\begin{array}{l}\text { Degree of } \\
\text { Contribution }\end{array}$ \\
\hline \multicolumn{4}{|l|}{ Information and Communication } \\
\hline \multicolumn{4}{|l|}{ Control Environment } \\
\hline $\begin{array}{l}\text { Commitment to honesty and ethical values contributes to strengthening: accountability, fairness, } \\
\text { responsibility, and transparency. }\end{array}$ & 4.78 & 0.48 & High \\
\hline $\begin{array}{l}\text { The commitment of the authorities given to each managerial level contributes to strengthening: } \\
\text { accountability, fairness, responsibility, and transparency. }\end{array}$ & 4.11 & 0.63 & High \\
\hline $\begin{array}{l}\text { The existence of an Audit Committee enhances: accountability, fairness, responsibility, and } \\
\text { transparency. }\end{array}$ & 4.79 & 0.52 & High \\
\hline $\begin{array}{l}\text { The existence of a clear philosophy of management about the importance of internal control and } \\
\text { determine the method of work contributes to strengthening: accountability, fairness, responsibility, } \\
\text { and transparency. }\end{array}$ & 4.80 & 0.71 & High \\
\hline $\begin{array}{l}\text { The existence of an organizational structure enhances: accountability, fairness, responsibility, and } \\
\text { transparency. }\end{array}$ & 4.51 & 0.38 & High \\
\hline $\begin{array}{l}\text { Assigning responsibilities contribute to strengthening: accountability, fairness, responsibility, and } \\
\text { transparency. }\end{array}$ & 4.57 & 0.65 & High \\
\hline $\begin{array}{l}\text { The existence of clear policies for human resources management enhances: accountability, } \\
\text { fairness, responsibility, and transparency. }\end{array}$ & 4.39 & 0.46 & High \\
\hline Overall average & 4.56 & 0.61 & High \\
\hline Risk Assessment & & & \\
\hline $\begin{array}{l}\text { Definition and analysis of risk by management when preparing the financial statements contribute } \\
\text { to strengthening: accountability, fairness, responsibility, and transparency. }\end{array}$ & 4.75 & 0.58 & High \\
\hline Control Activities & & & \\
\hline $\begin{array}{l}\text { Clearly defined policies and procedures established by the management to maintain assets and } \\
\text { determine the duties and authorities, as well as the independent evaluation of performance }\end{array}$ & 4.79 & 0.61 & High \\
\hline
\end{tabular}


contribute to strengthening: accountability, fairness, responsibility, and transparency.

Information and Communication

The existence of efficient information systems contributes to strengthening: accountability, $4.43 \quad 0.73 \quad$ High

fairness, responsibility, and transparency.

Using modern means of communication contributes to strengthening: accountability, fairness, $4.78 \quad 0.42 \quad$ High

responsibility, and transparency.

Overall average

$4.61 \quad 0.67 \quad$ High

Monitoring

The existence of bodies to supervise the quality of internal control performance and follow-up $4.84 \quad 0.53 \quad$ High

contribute to strengthening: accountability, fairness, responsibility, and transparency.

Overall statistics for all paragraphs of the contribution of commitment to internal control elements. $4.71 \quad 0.65 \quad$ High

\subsection{Hypotheses Testing}

The following hypotheses were tested using t-test at $95 \%$ degrees of confidence. According to the decision rule, the hypothesis would be accepted if the calculated ( $t$ ) is larger than tabulated ( $t$ ) (Zikmund, 2000). The results of this test are presented in Table 3.

Table 3. T-Test results to examine the hypotheses of the study

\begin{tabular}{lllll}
\hline Hypotheses & Mean & Calculated T & Tabulated T & Sig. \\
\hline $\mathrm{H} 1$ & 4.71 & 19.37 & 1.96 & 0.000 \\
$\mathrm{H} 1 / 1$ & 4.56 & 17.53 & 1.96 & 0.000 \\
$\mathrm{H} 1 / 2$ & 4.75 & 18.65 & 1.96 & 0.000 \\
$\mathrm{H} 1 / 3$ & 4.79 & 18.78 & 1.96 & 0.000 \\
$\mathrm{H} 1 / 4$ & 4.61 & 18.20 & 1.96 & 0.000 \\
$\mathrm{H} 1 / 5$ & 4.84 & 19.11 & 1.96 & 0.000 \\
\hline
\end{tabular}

Main hypothesis (H1):

As indicated in table 3, the value of calculated ( $t$ ) for the main hypothesis amounted to 19.37 with the significance level of 0.00 , which was larger than the tabulated $(t)$ value at the level of significance of 0.05 . These results proved that this hypothesis is accepted, which states that: "The commitment to internal control elements (control environment, risk assessment, control activities, information and communication, and monitoring) enhances the pillars of corporate governance (accountability, fairness, responsibility, and transparency)".

The major hypothesis is divided into five sub-hypotheses. The results of the t-test, as shown in table 3 , are as follows.

First sub-hypothesis (H1/1):

Table 3 shows that the value of calculated $(t)$ for this hypothesis reached 17.53 with the significance level of 0.00 , which was larger than the tabulated $(t)$ value at the level of significance of 0.05 . Therefore, this hypothesis is accepted, which states that: "The commitment to control environment enhances the pillars of corporate governance".

Second sub-hypothesis (H1/2):

Table 3 indicates that the value of calculated ( $\mathrm{t}$ ) for this hypothesis amounted to 18.65 with the significance level of 0.00 , which was greater than the tabulated $(\mathrm{t})$ value at the level of significance of 0.05 . Therefore, this hypothesis is accepted, which states that: "The commitment to risk assessment enhances the pillars of corporate governance".

Third sub-hypothesis (H1/3):

Table 3 illustrates that the value of calculated $(t)$ for this hypothesis amounted to 18.78 with the significance level of 0.00 , which was greater than the tabulated $(t)$ value at the level of significance of 0.05 . Based on the above, this hypothesis is accepted, which states that: "The commitment to control activities enhances the pillars of corporate governance".

Fourth sub-hypothesis (H1/4):

Table 3 illustrates that the value of calculated ( $t$ ) for this hypothesis amounted to 18.20 with the significance 
level of 0.00 , which was greater than the tabulated $(t)$ value at the level of significance of 0.05 . Based on the foregoing, this hypothesis is accepted, which states that: "The commitment to information and communication enhances the pillars of corporate governance".

Fifth sub-hypothesis (H1/5):

Table 3 shows that the value of calculated $(t)$ for this hypothesis reached 19.11 with the significance level of 0.00 , which was greater than the tabulated $(\mathrm{t})$ value at the level of significance of 0.05 . Therefore, this hypothesis is accepted, which states that: "The commitment to monitoring enhances the pillars of corporate governance".

The findings of this study are consistent with the results of many previous studies (e.g., Viriyanti, 2008; Susanty, 2009; Elbannan, 2009; Adeyemi \& Adenugba, 2011; Suyono \& Hariyanto, 2012; Fadilah, 2013).

\section{Conclusion}

The objective of this study was to explore the role of commitment to the elements of internal control in enhancing the corporate governance pillars as well as to determine the extent to which this commitment contributes to strengthening these pillars in the context of Jordanian insurance companies.

Like other prior studies, the results of this study indicated that the commitment to all elements of internal control contributes to strengthening the corporate governance pillars at a high degree, and the overall mean of this contribution was 4.71. The study also revealed that the commitment to each element of internal control contribute to strengthening the pillars of corporate governance at a high degree. This contribution was as follows: control environment with an average of 4.56, risk assessment with an average of 4.75 , control activities with an average of 4.79, information and communication with an average of 4.61 , and monitoring with an average of 4.84 .

Through the interpretation of the results, it is clear that the internal control has a significant role in enhancing the corporate governance pillars in Jordanian insurance companies, and the successes of corporate governance requires compliance with all elements of internal control.

The findings of this study have implications for senior management and internal auditors in Jordanian insurance companies by providing an insight into the relationship between corporate governance and internal control. Such insights suggest that the top management should be adhered to the proper implementation of internal control system in order to develop sound corporate governance to help increase Jordan's economic attraction and help ensure the rights and benefits of the business sector. The findings also encourage researchers to address other aspects concerning the relationship between the internal control and corporate governance in Jordan as an example of a developing country.

\section{References}

Adeyemi, B., \& Adenugba, A. (2011). Corporate governance in the Nigerian financial sector: The efficacy of internal control and external audit. Proceedings of the Global Conference on Business and Finance. San Jose, Costa Rica.

Aguilera, R. V., \& Jackson, G. (2003). The cross-national diversity of corporate governance: Dimensions and determinants. Academy of Management Review, 28(3), 447-465. http://dx.doi.org/10.5465/AMR.2003.10196772

Bosetti, L. (2008). Corporate governance and internal control: Evidence from local public utilities. Proceedings of the 2nd European Risk Conference. Milan, Italy.

Corporations Control Department (CCD). (2012). Jordanian corporate governance code. Retrieved from http://www.ccd.gov.jo

Dănescu, T., Prozan, M., \& Dănescu, A. C. (2011). Internal control activities: Cause and effect of a good governance of accounting reportings and fiscal declarations. Annales Universitatis Apulensis Series Oeconomica, 13(2), 339-349.

Dunne, P., \& Morris, G. (2008). Non-executive director's handbook (2nd ed.). London: CIMA Publishing.

Elbannan, M. A. (2009). Quality of internal control over financial reporting, corporate governance and credit ratings. International Journal of Disclosure and Governance, 6(2), 127-149. http://dx.doi.org/10.1057/jdg.2008.32

Fadilah, S. (2013). The influence of good governance implementation to organization performance: Analysis of factors affecting. The International Journal of Social Sciences, 7(1), 15-33. 
Hoitash, U., Hoitash, R., \& Bedard, J. C. (2009). Corporate governance and internal control over financial reporting: A comparison of regulatory regimes. The Accounting Review, 84(3), 839-867. http://dx.doi.org/10.2308/accr.2009.84.3.839

Jesover, F., \& Kirkpatrick, G. (2005). The revised OECD principles of corporate governance and their relevance to non-OECD countries. Retrieved 6 March, 2014, from http://www.oecd.org

Johnstone, K., Li, C., \& Rupley, K. H. (2011). Changes in corporate governance associated with the revelation of internal control material weaknesses and their subsequent remediation. Contemporary Accounting Research, 28(1), 331-383. http://dx.doi.org/10.1111/j.1911-3846.2010.01037.x

Jordan Insurance Federation. (2013). Retrieved 3 March, 2014, from http://www.joif.org

Khan, M. Y. (1994). Financial services (3rd ed.). India: Tata McGraw-Hill Publishing Company Ltd.

Khoury, N. S. (2003). Institutional control and the continuity of institutions, where does Jordan stand from institutional control? Proceedings of the 5th Professional Conference. Amman, Jordan.

King Committee on Corporate Governance. (2002). Executive summary of the king Report. Retrieved 8 March, 2014, from http://www.iodsa.co.za

Leng, J. F., \& Ding, Y. R. (2011). Internal control disclosure and corporate governance: Empirical research from Chinese listed companies. Technology and Investment, 2(4), 286-294. http://dx.doi.org/10.4236/ti.2011.24029

Lepadatu, G. V. (2011). Corporate governance and audit activity. Economy Transdisciplinarity Cognition, 14(1), 44-49.

Lin, Z. J., \& Liu, M. (2009). The impact of corporate governance on auditor choice: Evidence from China. Journal of International Accounting, Auditing and Taxation, 18(1), 44-59. http://dx.doi.org/10.1016/j.intaccaudtax.2008.12.005

Mensah, S., Aboagye, K., Addo, E., \& Buatsi, S. (2003). Corporate governance and corruption in Ghana: Empirical finding and policy implications. Proceedings of the African Capital Markets Forum. Johannesburg, South Africa.

Mihaela, D., \& Iulian, S. (2012). Internal control and the impact on corporate governance, in Romanian listed companies. Journal of Eastern Europe Research in Business \& Economics, 1-10. http://dx.doi.org/10.5171/2012.676810

Monks, R., \& Minow, N. (2004). Corporate governance (3rd ed.). London: Blackwell Publishing.

Njanike, K., Mutengezanwa, M., \& Gombarume, F. B. (2011). Internal controls in ensuring Good corporate governance in financial institutions. Annals of the University of Petroşani, Economics, 11(1), 187-196.

Organization for Economic Co-operation and Development (OECD). (2004). Principles of corporate governance. Retrieved 12 February, 2014, from http://www.oecd.org

Ping, T., \& Li, W. H. (2007). Research on reciprocal relationships between corporate governance and internal control. China-USA Business Review, 6(5), 1-9.

Rankin, M., Stanton, P., McGowan, S., Ferlauto, K., \& Tilling, M. (2012). Contemporary issues in accounting (1st ed.). Australia: John Wiley \& Sons Australia, Ltd.

Robbins, S. (1982). Essentials of organizational behavior (3rd ed.). London: Prentice Hall.

Romney, M., \& Steinbart, P. (2006). Accounting information systems (10th ed.). New Jersey: Person Prentice Hall.

Shanikat, M., \& Abbadi, S. S. (2011). Assessment of corporate governance in Jordan: An empirical study, Australasian Accounting Business and Finance Journal, 5(3), 93-106.

Steinthórsdóttir, L. (2004). Internal control-corporate governance, internal audit and strategic renewal. Monetary Bulletin, 6(1), 85-95.

Stone, A., Hurly, K., \& Khumani, R. (1998). Business environment and corporate governance: Strengthening incentives for private sector performance. Background papers for the World Bank/IMF Annual Meetings. Washington, D.C.

Susanty, A. (2009). The role of internal function of organization for the successful implementation of good corporate governance. World Academy of Science, Engineering and Technology, 58, 265-269. Retrieved 18 
April, 2014, from http://www.waset.org/journals/waset/v58.php

Suyono, E., \& Hariyanto, E. (2012). Relationship between internal control, internal audit, and organization commitment with good governance: Indonesian case. China-USA Business Review, 11(9), 1237-1245.

Viriyanti, N. P. (2008). The relationship between internal control and good corporate governance (survey on state owned enterprises in Bandung, Indonesia). Widyatama University Working paper. Widyatama University. Retrieved 25 February, 2014, from http://di.tamu.edu

Vlad, M. (2012). The corporative governance and internal audit. Case study: Romanian credit institutions. The USV Annals of Economics and Public Administration, 12(2/16), 164-169.

Weygandt, J. J., Kimmel, P. D., \& Kieso, D. E. (2011). Financial accounting (1st ed.). United States of America: John Wiley \& Sons, Inc.

Yuksel, C. (2008). Recent developments of corporate governance in the global economy and the new Turkish commercial draft law reforms, Journal of International Commercial Law and Technology, 3(2), 101-111.

Zikmund, W. G. (2000). Business research methods (6th ed.). London: Dryden Press.

\section{Copyrights}

Copyright for this article is retained by the author(s), with first publication rights granted to the journal.

This is an open-access article distributed under the terms and conditions of the Creative Commons Attribution license (http://creativecommons.org/licenses/by/3.0/). 